Inflammation, Vol. 13. No. 2, 1989

\title{
LYSOPHOSPHATIDES ENHANCE SUPEROXIDE RESPONSES OF STIMULATED HUMAN NEUTROPHILS ${ }^{1}$
}

\author{
ISAAC GINSBURG, ${ }^{2,3}$ PETER A. WARD, ${ }^{4}$ and \\ JAMES VARANI \\ ${ }^{2}$ Department of Oral Biology \\ Hebrew University-Hadassah School of Dental Medicine \\ Founded by the Alpha Omega Fraternity \\ Jerusalem, Israel \\ ${ }^{4}$ Department of Pathology \\ University of Michigan \\ Ann Arbor, Michigan 48109
}

\begin{abstract}
Human neutrophils which are pretreated with subtoxic concentrations of a variety of lysophosphatides (lysophosphatidylcholine, lysophosphatidylcholine oleoyl, lysophosphatidylcholine myrioyl, lysophosphatidylcholine stearoyl, lysophosphatidylcholine gamma- $O$-hexadecyl, lysophosphatidylinositol, and lysophosphatidylglycerol) act synergistically with neutrophil agonists phorbol myristate acetate, immune complexes, poly-L-histidine, phytohemagglutinin, and $N$-formylmethionyl-leucyl-phenyalanine to cause enhanced generation of superoxide $\left(\mathrm{O}_{2}^{-}\right)$. None of the lyso compounds by themselves caused generation of $\mathrm{O}_{2}^{-}$. The lyso compounds strongly bound to the neutrophils and could not be washed away. All of the lyso compounds that collaborated with agonists to stimulate $\mathrm{O}_{2}^{-}$generation were hemolytic for human red blood cells. On the other hand, lyso compounds that were nonhemolytic for red blood cells (lysophosphatidylcholine caproate, lysophosphatidylcholine decanoyl, lysophosphatidylethanolamine, lysophosphatidylserine) failed to collaborate with agonists to generate synergistic amounts of $\mathrm{O}_{2}^{-}$. However, in the presence of cytochalasin $B$, both lysophosphatidylethanolamine and lysophosphatidylserine also markedly enhanced $\mathrm{O}_{2}^{-}$generation induced by immune complexes. $\mathrm{O}_{2}^{-}$generation was also very markedly enhanced when substimulatory amounts of arachidonic acid or eicosapentanoic acid were added to PMNs in the presence of a variety of agonists. On the other hand, neither phospholipase $C$, streptolysin $S$ (highly hemolytic), phospholipase $A_{2}$, phosphatidylcholine, nor phosphatidylcholine dipal-
\end{abstract}

\footnotetext{
${ }^{3}$ Supported by a research grant from Dr. Samuel M. Robbins, Cleveland, Obio; by grant IM-432 from the American Cancer Society; and grants HL-28442-07, HL-31963, and GM-29507 from the National Institutes of Health, Bethesda, Maryland.

${ }^{3}$ Dr. Isaac Ginsburg was a visiting professor in the Department of Pathology at The University of Michigan when this research was conducted.
} 
mitoyl (all nonhemolytic) had the capacity to synergize with any of the agonists tested to generate enhanced amounts of $\mathrm{O}_{2}^{-}$. The data suggest that in addition to long-chain fatty acids, only those lyso compounds that possess fatty acids with more than 10 carbons and that are also highly hemolytic can cause enhanced generation of $\mathrm{O}_{2}^{-}$in stimulated PMNs.

\section{INTRODUCTION}

Recent studies from our laboratory (1-5) have described the role played by polycationic agents poly-L-arginine (PARG) and poly-L-histidine (PHSTD) as potent activators of the respiratory burst in human neutrophils (PMNs). It was also shown that a "cocktail" comprised of PARG, phytohemagglutinin, and cytochalasin $\mathrm{B}(\mathrm{CYB})$ caused generation of large amounts of superoxide $\left(\mathrm{O}_{2}^{-}\right)$ in human PMNs. Since a variety of cytolytic agents (lysophosphatidylcholine, digitonin, saponin) were able to replace PARG in the cocktail (5) and since PARG was also highly cytotoxic, we postulated that membrane-active agents including lysophosphatides might cause PMNs challenged with agonists known to activate the NADPH oxidase of PMNs $(6,7)$ to generate higher amounts of oxygen radicals. The present communication extends our earlier observations (5) and investigates in a systematic way the role played by lysophosphatides and certain fatty acids as potentiators of $\mathrm{O}_{2}^{-}$generation in stimulated PMNs. The possible role played by lysophosphatides as amplifiers of the inflammatory response is discussed.

\section{MATERIALS AND METHODS}

Blood Neutrophils (PMNs). Human blood in heparin ( 10 units $/ \mathrm{ml}$ ) was drawn from healthy donors. PMNs were isolated on a Ficoll-Hypaque gradient as described in detail elsewhere (4). Such preparations contained greater than $95 \%$ viable PMNs. Erythrocytes were removed by treatment with hypotonic saline followed by washing with nomal saline buffered with $0.01 \mathrm{M}$ phosphate, $\mathrm{pH}$ 7.3. The washed leukocytes were resuspended in Hanks' balanced salt solution (HBSS) buffered with 3 mM HEPES, pH 7.33, or in HBSS plus HEPES to which $10 \mathrm{mM}$ sodium azide was added and kept on ice. Viability of the PMNs was evaluated by the trypan blue exclusion technique

Measurement of Superoxide $\left(\mathrm{O}_{2}^{-}\right)$. Superoxide was determined in stimulated PMNs by the reduction of cytochrome $c$ ( $80 \mu \mathrm{M}$, type III, Sigma Chemical Company, St. Louis, Missouri) according to the method of Babior (7). The reaction mixtures contained $1-5 \times 10^{6} / \mathrm{ml} \mathrm{PMNs}$, and appropriate ligand (see below), cytochrome $c$, with or without $20 \mu \mathrm{g} / \mathrm{ml}$ superoxide dismutase (SOD) in a final volume of $1.0 \mathrm{ml}$. In some experiments, we examined the effect of $\mathrm{CYB}$ on $\mathrm{O}_{2}^{-}$ generation induced by the various ligands. The CYB was dissolved in dimethyl sulfoxide (DMSO) 
at $500 \mu \mathrm{g} / \mathrm{ml}$, and $2.5 \mu \mathrm{g} / \mathrm{ml}$ were employed. All reaction mixtures were incubated in a water bath at $37^{\circ} \mathrm{C}$ for various time intervals and then centrifuged at $1000 \mathrm{~g}$ for $5 \mathrm{mith}$. The optical density of supernatant ffuids was read $550 \mathrm{~nm}$. The amount of $\mathrm{O}_{2}^{-}$was calculated from the extinction values using the formula $\mathrm{E}_{550}=2.1 \times 10^{-4} \mathrm{M}$ and was expressed as nanomoles per given number of cells per 10 min.

Measurement of Hydrogen Peroxide $\left(\mathrm{H}_{2} \mathrm{O}_{2}\right)$. Hydrogen peroxide was determined in stimulated PMNs by the method described by Thurman et al. (9). Briefly, to stimulated PMNs in HBSS plus $\mathrm{NaN}_{3}(10 \mathrm{mM}$ ) (final volume of $1.0 \mathrm{ml}$ ), we added $200 \mu \mathrm{l}$ of TCA $(30 \%)$. The lubes were centrifuged at $1000 \mathrm{~g}$ for $5 \mathrm{~min}$. The clear supernates were transferred to clean tubes, and $200 \mu \mathrm{l}$ of $\mathrm{Fe}\left(\mathrm{NH}_{4}\right)_{2}\left(\mathrm{SO}_{4}\right) \cdot 6 \mathrm{H}_{2} \mathrm{O}(19 \mathrm{mg} / 5 \mathrm{ml}$ of water) plus $100 \mu \mathrm{l}$ of KCNS (25\%) were added. The tubes were agitated and incubated for $5 \mathrm{~min}$ at room temperature, and the brown color that developed was read in a spectrophotometer at $480 \mathrm{~nm}$. A standard curve for hydrogen peroxide was prepared on the day of the experiment. The results were expressed as nanomoles per number of leukocytes per $10 \mathrm{~min}$. Catalase $(100 \mu \mathrm{g} / \mathrm{ml}$, from bovine liver, 17,600 Sigma units $/ \mathrm{mg}$ protein) was included in control tubes.

Stimulation of Oxygen Radical Generation. PMNs $\left(1-3 \times 10^{6} / \mathrm{ml}\right)$ in HBSS containing sodium azide $\left(10 \mathrm{mM}\right.$ ) were treated for $15 \mathrm{~min}$ at $37^{\circ} \mathrm{C}$ with (A) PHSTD (molecular weight 15,000 ); (B) an immune complex (8) prepared by mixing $50 \mu \mathrm{l}$ of a rabbit anti-bovine serum albumin (BSA) immune globulin containing $2 \mathrm{mg}$ of protein nitrogen $/ \mathrm{ml}$, with $25 \mu \mathrm{g}$ of BSA $(6 \mathrm{mg} / \mathrm{ml})$ (the restlting precipate was washed in saline and resuspended to the same volume); and (C) lipoteichoic immune complex [PMNs were pretteated for $10 \mathrm{~min}$ at $37^{\circ} \mathrm{C}$ with $25 \mu \mathrm{g} / \mathrm{ml}$ of lipoteichoic acid (LTA) derived from Streptococcus pyogenes (10); the PMNs were washed in HBSS and treated with a rabbit anti-LTA globulin containing $250 \mu \mathrm{g}$ protein $/ \mathrm{ml}$ in the presence of a cytochrome $\mathrm{c}$; (D) the chemotactic peptide formyl-methionyl-leucyl-phenylalanine (FMLP) $\left(10^{-5}-10^{-8} \mathrm{M}\right.$ ); (E) phytohernagglutinin (PHA $50 \mu \mathrm{g} / \mathrm{ml}$ ) derived from Phaseoulus vulgaris; (F) phorbol myristate acetate (PMA) $(1-5 \mu \mathrm{g} / \mathrm{ml})$; and (G) streptococci opsonized with rabbit anti-streptococcal serum and with complement (10).

Modulation of $\mathrm{O}_{2}^{-}$Generation. The following agents were tested for their capacity to modulate the generation of $\mathrm{O}_{2}^{-}$and $\mathrm{H}_{2} \mathrm{O}_{2}: \mathrm{L}-\alpha$-lysophosphatidylcholine from egg yolk, from bovine brain, and from bovine liver; $L-\alpha$-lysophosphatidylcholine caproyl; $L-\alpha$-lysophosphatidylcholine oleyl; $L-\alpha-l y s o p h o s p h a t i d y l c h o l i n e ~ d e c a n o y l ; ~ L-\alpha-l y s o p h o s p h a t i d y l c h o l i n e ~ m y r i s t o y l ; ~ L-\alpha-l y s o-$ phosphatidylcholine stearoyl; DL- $\alpha$-lysophosphatidylcholine gamma- $O$-hexadecyi; L- $\alpha$-lysophosphatidic acid oleyl sodium; L- $\alpha$-lysophosphatidyl L- $\alpha$-serine; lysophosphatidylethanolamine; L- $\alpha-$ lysophosphatidyljnositoi; L- $\alpha$-lysophosphatidyl DL-glycerole; phosphatidylcholine; DL- $\alpha$-phosphatidylcholine dipalmytoyl; palmitic acid; arachidonic acid; 5,8,11,15,17-eicosapentonic acid; phospholipase $\mathrm{A}_{2}$ (from bee venom); phospholipase $\mathrm{A}_{2}$ (from Naja Naja); phospholipase $\mathrm{C}$ (from Clost. welchii); and streptolysin $\mathbf{S}$. All these agents were obtained from Sigma Chemical Company. The agents were either dissolved in saline or in ethanol followed by the addition of boiling water. All materials were kept at $-20^{\circ} \mathrm{C}$. Human PMNs $\left(1-3 \times 10^{6} / \mathrm{ml}\right)$ in HBSS containing cytochrome $c$ were pretreated for $1 \mathrm{~min}$ at foom temperature with the various agents followed by the addition of a series of agonists (see above). In some experiments CYB $(2.5 \mu \mathrm{g} / \mathrm{ml}$ ) was included in the reaction mixtures. We also tested the superoxide-generating capacities of the various materials in the absence of added agonist.

Determination of Hemolytic Activity. One-milliliter aliquots of $1 \%$ suspension of human red blood cells in HBSS were treated for $15 \mathrm{~min}$ at $37^{\circ} \mathrm{C}$ with the various lipids or enzymes. The tubes were centrifuged at $1000 \mathrm{~g}$ for $5 \mathrm{~min}$, and the degree of hemolysis was assayed by measuring the absorption at $540 \mathrm{~nm}$ of the hemoglobin released. One hemolytic unit was determined to be as the smallest amount of agent that released $50 \%$ of the hemoglobin after $15 \mathrm{~min}$ of incubation. 


\section{RESULTS}

Synergistic Effect of Lyso Compounds and Various Agonists in Superoxide Generation. Since lyso compounds are generally known to be hemolytic for red blood cells and cytotoxic for nucleated cells, we first determined the ID $_{50}$ for the various agents employing human red blood cells as targets. Table 1 shows that, except for lysophosphatidylcholine caproate, lysophosphatidylcholine decanoyl, lysophosphatidylethanolamine, and lysophosphatidylserine, all of the other lysocompounds tested were hemolytic for red blood cells at concentrations ranging from 5 to $10 \mu \mathrm{M}$. The various 'yso compounds were tested for their capacity to enhance $\mathrm{O}_{2}^{-}$generation in PMNs stimulated by various agonists using concentrations that induced less than $50 \%$ hemolysis of red blood

Table 1. Superoxide-Enhancing and Hemolytic Activities of Various Agents

\begin{tabular}{|c|c|c|}
\hline \multirow[b]{2}{*}{ Compound tested ${ }^{a}$} & \multicolumn{2}{|c|}{ Molarity inducing } \\
\hline & Hemolysis & $\mathrm{O}_{2}^{-}$enhancement \\
\hline Lysophosphatidylcholine (egg yolk) & $8 \mu \mathrm{M}$ & $1-3 \mu \mathrm{M}$ \\
\hline Lysophosphatidylcholine (brain) & $8 \mu \mathrm{M}$ & $1-4 \mu \mathrm{M}$ \\
\hline Lysophosphatidylcholine (liver) & $8 \mu \mathrm{M}$ & $1-4 \mu \mathrm{M}$ \\
\hline Lysophosphatidylcholine caproate & None $(10 \mathrm{mM})$ & None $(10 \mathrm{mM})$ \\
\hline Lysophosphatidylcholine decanoyl & None $(10 \mathrm{mM})$ & None $(10 \mathrm{mM})$ \\
\hline Lysophosphatidylcholine oleyl & $10 \mu \mathrm{M}$ & $3-5 \mu \mathrm{M}$ \\
\hline Lysophosphatidylcholine myristoyl & $20 \mu \mathrm{M}$ & $5-7 \mu \mathrm{M}$ \\
\hline Lysophosphatidylstearoyl & $6 \mu \mathrm{M}$ & $2.5-4.0 \mu \mathrm{M}$ \\
\hline Lysophosphatidylcholine-O-hexadecyl & $15 \mu \mathrm{M}$ & $2-5 \mu \mathrm{M}$ \\
\hline \multicolumn{3}{|l|}{ Lysophosphatidic acid oleyl } \\
\hline Lysophosphatidylethanolamine & None $(10 \mathrm{mM})$ & None $(10 \mathrm{mM})^{h}$ \\
\hline Lysophosphatidylserine & None $(18 \mathrm{mM})$ & None $(100 \mathrm{mM})^{b}$ \\
\hline Lysophosphatidylinositol & $15 \mu \mathrm{M}$ & $5-12.5 \mu \mathrm{M}$ \\
\hline Lysophosphatidylglycerole & $20 \mu \mathrm{M}$ & $1-2 \mu \mathrm{M}$ \\
\hline Arachidonic acid & None $(200 \mu \mathrm{M})$ & $30-50 \mu \mathrm{M}$ \\
\hline Eicosapentanoic acid & None $(200 \mu \mathrm{M})$ & $30-50 \mu \mathrm{M}$ \\
\hline Palmitic acid & $500-700 \mu \mathrm{M}$ & $10-20 \mu \mathrm{M}$ \\
\hline Phospholipase $\mathrm{A}_{2}$ (bee venom) & None (25 units/ml) & None \\
\hline Phospholipase $\mathrm{A}_{2}$ (Naja naja) & None (25 units/mI) & None \\
\hline Phospholipase C & 0.0125 units $/ \mathrm{ml}$ & None \\
\hline Streptolysin S & $100 \mathrm{H}$ units/ml & None \\
\hline
\end{tabular}

"PMNs were treated for $1 \mathrm{~min}$ at room temperature with the various compounds. The concentrations of the various agents employed to enhance $\mathrm{O}_{2}^{-}$generation were below their hemolytic activity for a $1 \%$ suspension of human red blood cells. $\mathrm{O}_{2}^{-}$generation was initiated either by BSA immune complex, poly-L-histidine, or PMA.

${ }^{i} \mathrm{~A}$ matked enhancement of $\mathrm{O}_{2}^{-}$generation took place only in the presence of $\mathrm{CYB}$ (see Figure 6). 
cells. Nonlytic compounds were tested at a wider range of concentrations. Figures 1-5 show the synergistic effects of lysophosphatides with a variety of agonists on $\mathrm{O}_{2}^{-}$generation. All the lyso compounds that enhanced $\mathrm{O}_{2}^{-}$generation also increased the production of hydrogen peroxide (not shown). None of the lyso compounds by themselves caused $\mathrm{O}_{2}^{-}$generation when employed in the absence of neutrophil agonists. Table 1 also shows that all the other lyso compounds that hemolysed red blood cells also had the capacity to enhance $\mathrm{O}_{2}^{-}$ generation in stimulated PMNs. Of the lysophosphatides that failed to enhance $\mathrm{O}_{2}^{-}$generation, two possessed fatty acids with less than 11 carbons (lysophosphatidylcholine caproate and lysophosphatidylcholine decanoyl). The other two nonactive compounds had a polar base (lysophosphatidylserine and lysophosphatidylethanolamine). Table 1 also shows that not all the agents that were hemolytically active enhanced $\mathrm{O}_{2}^{-}$generation in stimulated PMNs. Specifically, neither phospholipase $\mathrm{C}$ nor streptolysin $\mathrm{S}$ affected the $\mathrm{O}_{2}^{-}$response in neutrophils.

Since CYB is known to enhance $\mathrm{O}_{2}^{-}$generation induced by a variety of both soluble and particulate agents $(2,11,12)$, it was of interest to determine whether lyso compounds that were nonhemolytic and did not enhance $\mathrm{O}_{2}^{-}$generation might do so in the presence of $\mathrm{CYB}$. Figure 6 shows that in the presence

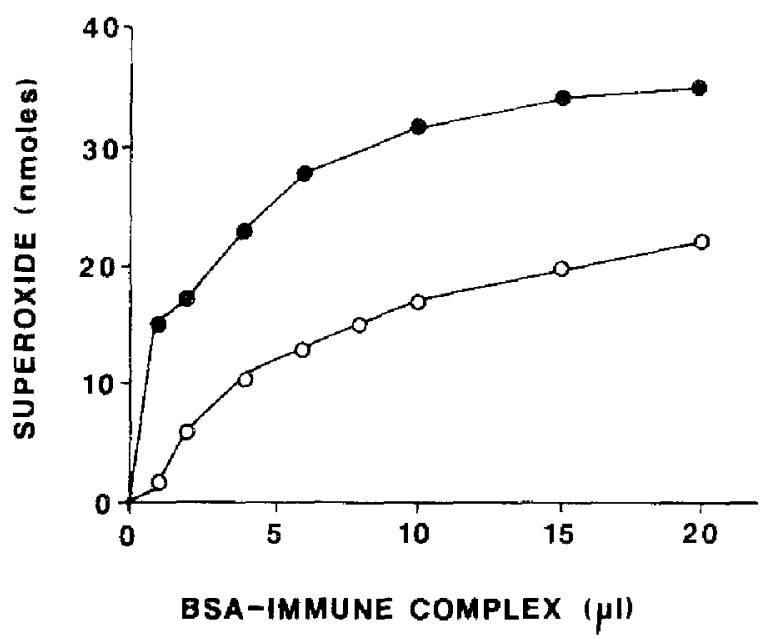

Fig. 1. Effect of lysophosphatidylcholine (LL) on $\mathrm{O}_{2}^{-}$generation induced by BSA immune complex. PMNs $\left(2 \times 10^{6} / \mathrm{ml}\right)$ were treated with inereasing amounts of BSA complex in the absence $(\mathrm{O}-\mathrm{O})$ and in the presence of LL $(2.5 \mu \mathrm{g} / \mathrm{ml}(--)$. Note the marked enhancement of $\mathrm{O}_{2}^{-}$generation in the presence of LL and that LL by itself did not generate $\mathrm{O}_{2}^{-}$above the control levels. 


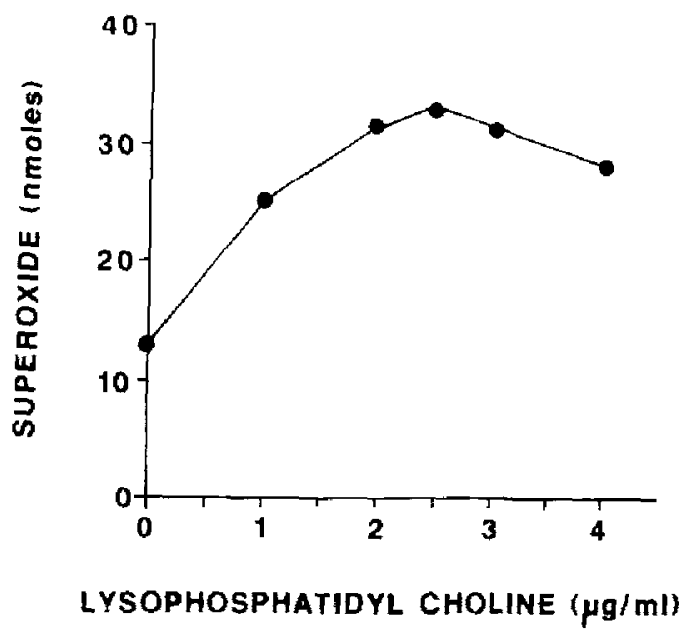

Fig. 2. Effect of lysophosphatidylcholine (LL) on $\mathrm{O}_{2}^{-}$generation induced by lipoteichoic acid immune complex. PMNs $\left(3 \times 10^{6} / \mathrm{ml}\right)$ were pretreated for $15 \mathrm{~min}$ with lipoteichoic acid (LTA). The cells were washed and resuspended in HBSS and further treated for $1 \mathrm{~min}$ at room temperature with increasing amounts of $\mathrm{LL}$ followed by the addition of anti-LTA globulin $(250 \mu \mathrm{g} \mathrm{protein} / \mathrm{ml})$. Note that maximal stimulation of $\mathrm{O}_{2}^{-}$generation - took place with $2.5 \mu \mathrm{g} / \mathrm{ml}$ of $\mathrm{LL}$, which is below its lytic capacity for red blood cells (see Table 1). LL by itself did not generate $\mathrm{O}_{2}^{-}$.

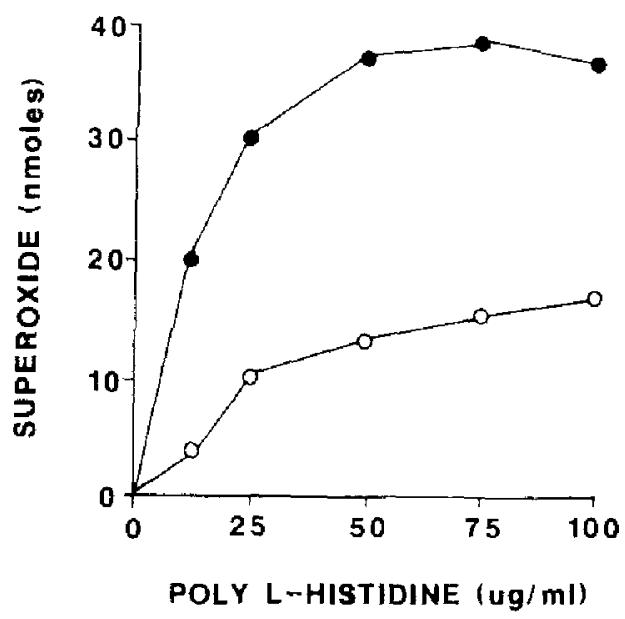

Fig. 3. Effect of lysophosphatidylcholine (LL) on $\mathrm{O}_{2}^{-}$generation by poly-L-histidine (PHSTD). Untreated PMNs $\left(2 \times 10^{6} / \mathrm{ml}\right)(\mathrm{O}-\mathrm{O})$ and PMNs pretreated for $1 \mathrm{~min}$ at room temperature with LL $(2.5 \mu \mathrm{g} / \mathrm{mI})(-\bullet)$ were challenged with increasing amounts of PHSTD. Note the marked enhancement of $\mathrm{O}_{2}^{-}$generated by the combined effect of LL and PHSTD. 


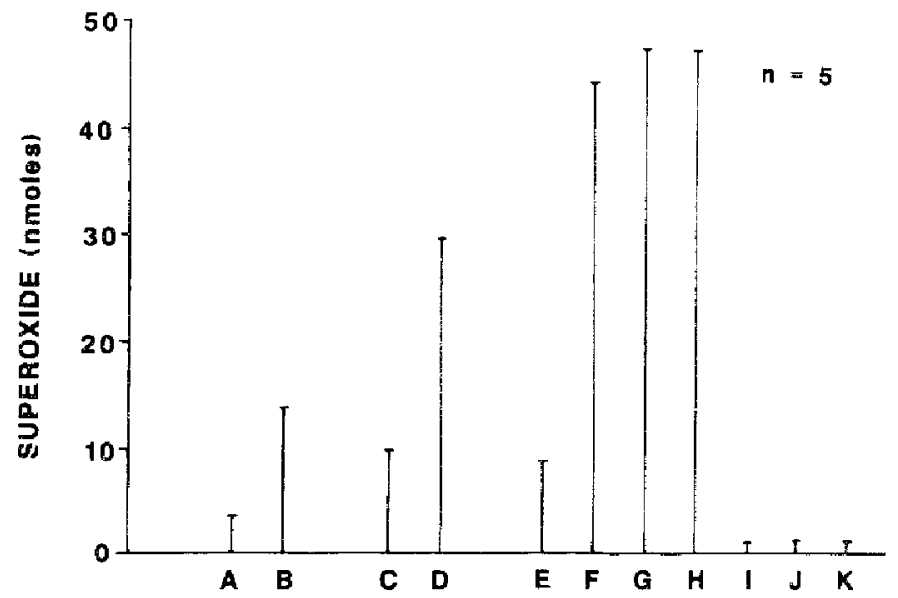

Fig. 4. Effect of lysophosphatides on $\mathrm{O}_{2}^{-}$generation induced by various agonists. PMNs $\left(3 \times 10^{5} /\right.$ $\mathrm{ml}$ ) were treated with (A) FMLP $\left(10^{-6} \mathrm{M}\right)$, (B) FMLP + LL $(2.5 \mu \mathrm{g} / \mathrm{ml})$, (C) phytohemagglutinin (PHA) $(50 \mu \mathrm{g} / \mathrm{ml})$, (D) PHA + LL, (E) PMA (3 ng/ml), (F) PMA + LL, (G) PMA + lysophosphatidylglycerole $(1.5 \mu \mathrm{g} / \mathrm{ml})$, (H) PMA + lysophosphatidylinositol $(2.5 \mu \mathrm{g} / \mathrm{ml})$, (I) LL alone, (J) lysophosphatidylglycerol alone, and $(K)$ lysophosphatidylinositol alone. Note the enhanced generation of $\mathrm{O}_{2}^{-}$induced by the combination of lysophosphatides and various agonists.

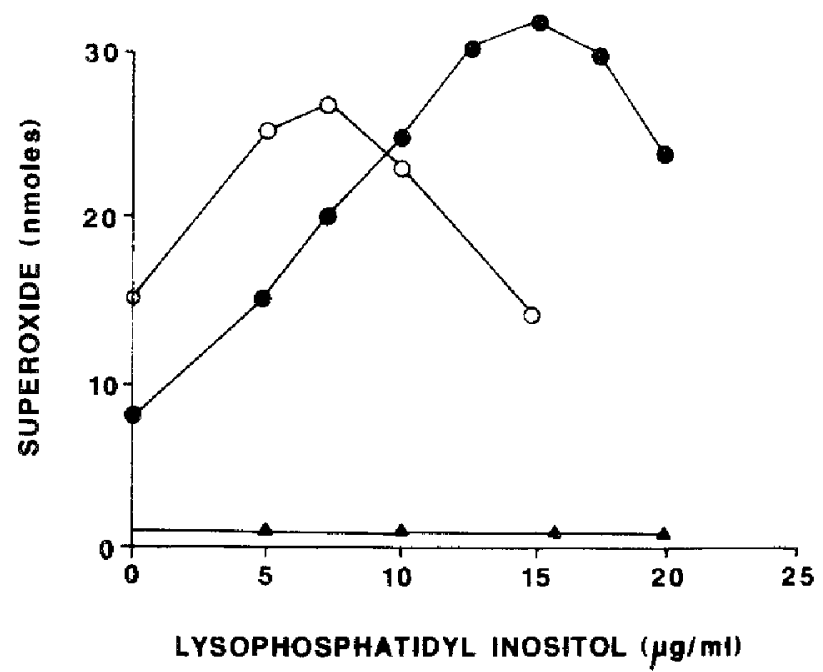

Fig. 5. Effect of lysophosphatidylinositol (LPI) on $\mathrm{O}_{2}^{-}$generation induced by two agonists. PMNs $\left(2 \times 10^{6} / \mathrm{ml}\right)$ were pretreated for $1 \mathrm{~min}$ at room temperature with increasing amounts of LPI. The cells were then challenged either with poly-L-Histidine (PHSTD) $(75 \mu \mathrm{g} / \mathrm{ml})(O-O)$ or with BSA immune complex $(7.5 \mu \mathrm{l})(-)$. Note the distinct synergistic effects of the lysophosphatides with the two agonists on $\mathrm{O}_{2}^{-}$generation. LPI alone $(-\ldots)$ had no $\mathrm{O}_{2}^{-}$generating ability. 
of CYB even lysophosphatidylethanolamine and lysophosphatidylserine (not shown) were highly stimulatory to $\mathrm{O}_{2}^{-}$generation when immune complexes or PHSTD were employed as agonists.

Since the stimulatory effects of the various lyso compounds might be related to the presence of free fatty acid contaminating the preparations and since fatty acids have been shown to trigger $\mathrm{O}_{2}^{-}$generation by PMNs $(13,14)$, we tested the capacity of certain fatty acids to enhance $\mathrm{O}_{2}^{-}$generation in stimulated PMNs. Figure 7 shows that both aracidonic acid and eicosapentanoic acid at $10 \mu \mathrm{M}$ (nonhemolytic at concentrations up to $200 \mu \mathrm{M}$ ) (Table 1) also markedly enhanced $\mathrm{O}_{2}^{-}$generation induced by PMA. Similar results (not shown) were also obtained when PHSTD or BSA immune complex were the agonists. Under similar conditions at concentrations up to $10 \mu \mathrm{M}$, palmitic acid was only slightly stimulatory when employed in conjunction with either PMA, PHSTD, or with

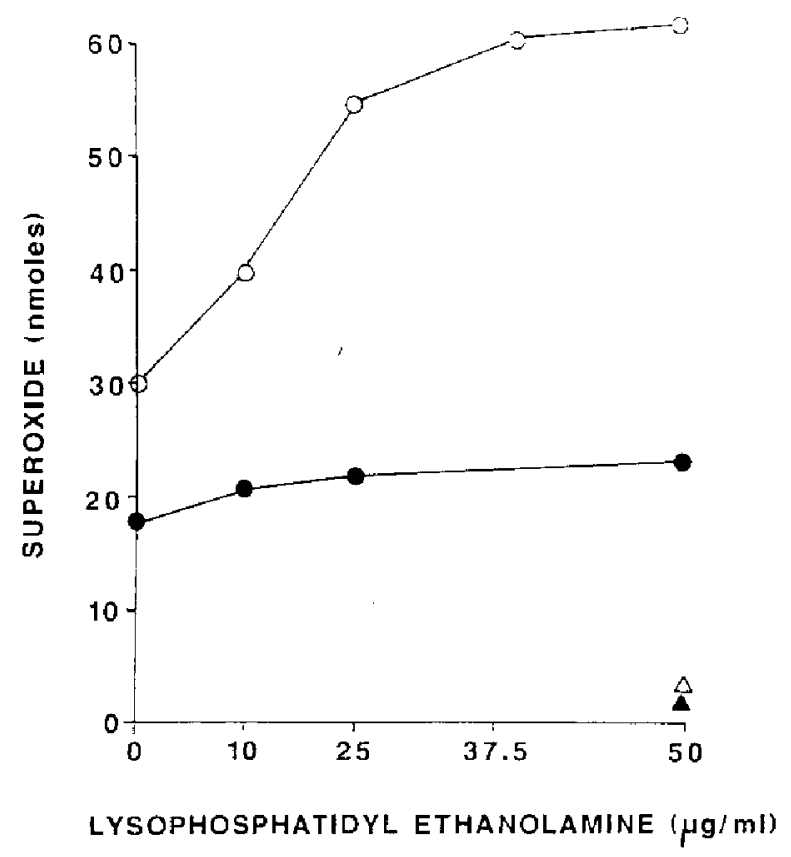

Fig. 6. Effect of $\mathrm{CYB}$ on $\mathrm{O}_{2}^{-}$generation induced by lysophosphatidylethanolamine (LPEA) in the presence of BSA immune complex. PMNs $\left(2 \times 10^{6} / \mathrm{mi}\right)$ were pretreated for 1 min at room temperature with increasing amounts of LPEA. The cells were then further treated with BSA complex $(7.5 \mu 1)$ in the absence $(-\bullet)$ and presence of CYB $(2.5 \mu \mathrm{g} / \mathrm{ml})(\mathrm{O}-\mathrm{O})$. Note that while in the absence of CYB, LPEA failed to generate appreciable amounts of $\mathrm{O}_{2}^{-}$, a distinct synergistic generation of $\mathrm{O}_{2}^{-}$took place when PMNs were simultaneously treated with LPEA, BSA complex, and CYB. Neither LPEA $(\Delta)$ nor LPEA + CYB $(\Delta)$ in the absence of added agonist had the capacity to generate $\mathrm{O}_{2}^{-}$. 


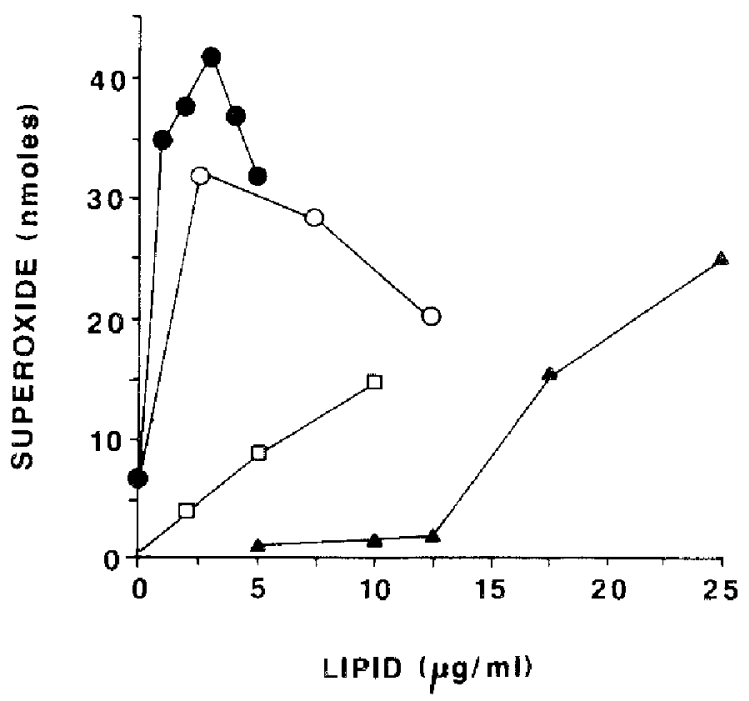

Fig. 7. Effect of free fatty acids on $\mathrm{O}_{2}^{-}$generation induced by PMA. PMNs $\left(2 \times 10^{6} / \mathrm{ml}\right)$ were treated with increasing amounts of arachidonic acid (AA) $(\boldsymbol{\Lambda}-\mathbf{\Delta})$, eicosapentanoic acid (EICO) $(\square-\square)$ with AA + PMA $(33 \mathrm{ng} / \mathrm{ml})(\mathrm{O}-\mathrm{O})$ and with EICO + PMA $(\bullet-\bullet)$. Note the distinct synergistic generation of $\mathrm{O}_{2}^{-}$when fatty acids act in collaboration with PMA. The concentrations of the fatty acids that enhanced $\mathrm{O}_{2}^{-}$generation in the presence of an agonist were far below those that induced $\mathrm{O}_{2}^{-}$generation in its absence.

immune complexes (not shown). It should be noted that based on the doseresponses as compared to the amounts of lysophosphatidylcholine (Figure 1) required for enhancement of $\mathrm{O}_{2}^{-}$responses in stimulated PMNs, it seems unlikely that the effect of the lysophosphatidyl compounds can be ascribed to presence of contaminating free fatty acids.

\section{DISCUSSION}

The data presented show that the generation of $\mathrm{O}_{2}^{-}$by human PMNs is greatly enhanced in the cells that are pretreated with lysophosphatides and then challenged with a variety of agonists (Table 1, Figures 1-5).

The direct correlation between the hemolytic activity of the various lyso compounds and their capacity to synergize with agonists to generate enhanced amounts of $\mathrm{O}_{2}^{-}$is striking (Table 1). Nonhemolytic compounds (lysophosphatidylcholine caproate, lysophosphatidylcholine decanoyl), that failed to hemolyse red blood cells also failed to act synergistically with neutrophil agonists. Since these compounds possess fatty acids with less than 11 carbons, it appears 
that the length of the fatty acid chain might play an important role as a membrane permeabilizing agent. Furthermore, since both lysophosphatidylserine and lysophosphatidylethanolamine (which contain primarily stearic and palmitic acid) also failed either to hemolyse or to synergize with the agonists, we suggest that the presence of polar groups in these substances interfered with the permeabilization of the membrane or with the $\mathrm{O}_{2}^{-}$-generating system. Since the concentrations of the various lyso compounds that acted synergisticaliy with the agonists were not cytotoxic, it appears that the various agents first interacted with some phospholipid targets in the PMNs membrane. This interaction "primed" the oxidase, which was then fully activated by a "second hit" (5, 6). Since none of the lysophosphatides employed in this study had the capacity to induce $\mathrm{O}_{2}^{-}$generation in the absence of added agonist (see also 13), these compounds differ from digitonin (15) and from free fatty acids (14), which are efficient $\mathrm{O}_{2}^{-}$-generating agents. Quantitatively, however, much larger amounts of the free fatty acids are needed to generate comparable amounts of $\mathrm{O}_{2}^{-}$(Figure 7). It seems, therefore, that the capacity of the various lyso compounds to synergize with the agonists is not due to contamination with free fatty acids.

Since two hemolytic agents (phospholipase $\mathrm{C}$ and streptolysin S) failed to synergize with the various agonists in $\mathrm{O}_{2}^{-}$generation, it appears that not every membrane-active agent has the capacity to prime the oxidase in the membrane. The mechanism by which the various lytic agents augment $\mathrm{O}_{2}^{-}$generation in the presence of other agonists is not fully known. The inability of phospholipase $\mathrm{A}_{2}$ and phospholopase $\mathrm{C}$, when added externally, to stimulate $\mathrm{O}_{2}^{-}$generation is intriguing. Since activation of NADPH oxidase is known to involve the activation of the inositol phosphatide cascade (16-20) and the release of arachidonic acid from membrane phospholipids with the concomitant accumulation of lyso compounds, it appears that when added externally these phospholipases fail to gain access to their substrates, which are the products involved in the ultimate activation of the oxidase. This can be achieved, however, by adding the degradation product of phospholipase $\mathbf{A}_{2}$, namely lysophosphatide. Further studies employing thin-layer chromatography might reveal whether or not the interaction of PLA $\mathrm{P}_{2}$ with the cells resulted in the accumulation of lyso compounds in the membrane.

More recently (21) it was also shown that lysophosphatidylcholine enhanced the generation of $\mathrm{O}_{2}^{-}$induced by various soluble agonists. On the other hand, no such stimulation occurred when opsonized zymosan was the agonist. Our results vary from those described (21) in several aspects and add new observations. (1) Employing similar concentrations of the various lyso compounds, we found a direct correlation between the length of the fatty acids present in the various compounds and their hemolytic and $\mathrm{O}_{2}^{-}$-generating capacities (Table 1). (2) Although lysophosphatidylserine and lysophosphatidylethanolamine failed to enhance $\mathrm{O}_{2}^{-}$generation when tested with the various 
agonists (21), they did so in the presence of CYB (Figure 6). (3) The degree of stimulation obtained in our studies is much larger than that described (21) (Figures 1-5). (4) Not only lyso compounds, but also fatty acids such as arachidonic acid and eicosapentanoic acid, proved very effective primers of the oxidase when employed in collaboration with a variety of agonists (Figure 7). (5) The lyso compounds also markedly stimulated $\mathrm{O}_{2}^{-}$generation by particulate agents such as opsonized streptococci (not shown) and by two immune complexes (Figures 1-3). Since it was found that nonmetabolizable analogs of platelet-activating factor were also active as stimulators of $\mathrm{O}_{2}^{-}$generation in the presence of PMA (21), it is unlikely that the enhancement of $\mathrm{O}_{2}^{-}$generation was due to the acetylation of the lyso compounds to generate platelet activating factor.

The significance of the synergistic effect of lysophosphatides with other agonists in the generation of large amounts of $\mathrm{O}_{2}^{-}$might be important in sites of inflammation. Large amounts of lipid material are known to accumulate in inflamed sites. PLA 2 released from activated PMNs or macrophages might generate lyso compounds that further coliaborate with other agonists, e.g., immune complexes, chemotactic peptide, etc., to generate large amounts of toxic oxygen species.

\section{REFERENCES}

1. Ginsburg, I., R. Bortnski, M. Lahav, D. E. Gillert, S. Falkenberg, M. Winkler, and S. Muller. 1982. Bacteria and zymosan opsonized with histone, dextran sulfate and polyanethole-sulfonate trigger intense chemiluminescence in human blood leukocytes and platelets and in mouse peritoneal macrophages: Modulation by metabolic inhibitors in relation to leukocyte-bacteria interaction in inflammatory sites. Inflammation 6:343-364.

2. Ginsburg, I., R. Boronski, D. Malamud, F. Struckmayer, and V. Klimetzek. 1985. Chemiluminescence and superoxide generation by leukocytes stimulated by polyelectrolyte opsonized bacteria: Role of histone, polyarginine, polylysine, polyhistidine, cytochalasins, and inflammatory exudates as modulators of the oxygen burst. Inflanmation 9:245-271.

3. Ginsblrg, I., R. Borinski, M. Lahav, Y. Matzner, i. Eliasson, P. Christensex, and D. MALAMUD. 1984. Poly-L-arginine and $N$-formylated chemotactic peptide act synergistically with lectins and calcium ionophore to induce intense chemiluminescence and superoxide production by human blood leukocytes: Modulation by metabolic inhibitors, sugars and polyelectrolytes. Inflammation $8: 1-26$.

4. Ginsblrg, I., R. Borjnski, M. Sadsvnik, Y. Ellam, and K. RaInsford. 1987. Poly-L-histidine. A potent stimulator of superoxide generation in human blood leukocytes. Inflammation 11:253-277.

5. Ginsburg, 1., R. Borinski, and M. PABST, 1985. NADPH and "cocktails" containing polyarginine reactivate superoxide generation in leukocytes lysed by membrane-damaging agents. Inflammation 9:341-363.

6. McPhail, L. C. P. M. Henson, and R. B. Johnstok. 1981. Respiratory burst in human neutrophils. Evidence for multiple mechanism of activation. J. Clin. Invest. 67:710. 
7. BABIOR, B. M. 1978. Oxygen-dependent microbial killing by phagocytes. N. Engl. J. Med. 298:721-725.

8. Ward, P. A., R. E. Duque, M. C. Sulavik, and K. J. Johnson. 1983. In vitro and in vivo stimulation of rat neutrophils and alveolar macrophages by immune complexes. Production of $\mathrm{O}_{2}^{-}$and $\mathrm{H}_{2} \mathrm{O}_{2}$. Am. J. Pathol. 110:297-309.

9. Thurman, R. G., H. G. LeyAnd, and R. SCHOLz. 1972. Hepatic microsomal ethanol oxidation hydrogen peroxide formation and tole of catalase. Eur. J. Biochem. 25:420.

10. GINSBLRG, I. 1988. Lipoteichoic acid-anti-lipotechoic complexes induce superoxide generation by human neutrophils. Inflammation 12:525-548.

11. Malawista, S. E., J. B. L. Gee, and K. G. BeNCh. 1971. Cytochalasin reversibly inhibits phagocytosis: Functional, metabolic and ultrastructural effects in human blood leukocytes and in rabbit alveolar macrophages. Yale J. Biol. Med. 44:286.

12. Lehmeyer, J, E., R. SNyderman, and R. B. Johnston, JR. 1989. Stimulation of neutrophil oxidation metabolism by chemotactic peptides: Influence of calcium irons, concentration of cytochalasin B and comparison with stimulation by phorbole myristate acetate. Blood 54:35.

13. BRomberg, Y., and E. PICK. 1983. Unsaturated fatty acids as second messengers of superoxide generation in macrophages. Cell. Immunol. 79:240-252.

14. Badwey, J. A., J. T. Curnutte, O. N. Robins, C. B. Brede, M. J. Karnovsky, and M. L. KARNOVSKY. 1984. Effect of free fatty acids on release of superoxide and on change of shape of human neutrophils. J. Biol. Chem. 259:7870-7877.

15. COHEN, H. J., and M. E. ChOvaniEC. 1978. Superoxide generation by digitonin-stimulated guinea pig granulocytes. A basis of continuous assay for monitoring superoxide production. J. Clin. Invest. 61:1081.

16. Nismzuka, Y. 1984. Tumover of inositol phospholipids and signal transduction. Science 225:1365-1370.

17. Doygherty, R. W., P. P. Godfrey, J. W. Putney, and R. J. Freer. 1984. Secretagogue induced phosphoinositide metabolism in human leukocytes. Biachem. J. 222:307-314.

18. Downes, C. P., and R. H. Michell. 1985. Inositol phospholipid breakdown as a receptor controlled generator of second messengers. In Molecular Mechanisms of Transmembrane Signalling. P. Cohen and M. D. Houslay, editors. 3-56.

19. Smith, C. D., B. C. Lane, I. Kusaki, M. W. Verghese, and R. Snyderman. 1985. Chemoattractant receptor-induced hydrolysis of phosphatidylinositol 4.5 bisphosphate in human polymorphonuclear leucocyte membrane. $J$. Biol. Chem. 260:5875-5878.

20. HURST, N. P. 1987. Molecular basis of activation and regulation of the phagocytic respiratory burst. Arn. Rheuma. Dis. 46:265-272.

21. Engelberger, W., D. Bitter-Suermank, and U. Hadding. 1987. Influence of lysophosphoiipids and PAF on the oxidative burst. Int. J. Inmunopharmacol. 9:275-282. 